\title{
MEASURING SOCIAL-PSYCHOLOGICAL FUNCTIONING AMONG MALAYSIAN PRE-SERVICE TEACHERS
}

\author{
Ahmad Zamri Khairani ${ }^{1 *}$, Izazol Idris ${ }^{2}$ and Hasni Shamsuddin ${ }^{1}$ \\ ${ }^{1}$ School of Educational Studies, Universiti Sains Malaysia, 11800 USM \\ Pulau Pinang, Malaysia \\ ${ }^{2}$ Faculty of Human Development, Universiti Pendidikan Sultan Idris, \\ 35900 Tanjung Malim, Perak, Malaysia \\ *Corresponding author: ahmadzamri@usm.my
}

Published date: 31 March 2019

To cite this article: Ahmad Zamri Khairani, Izazol Idris, \& Hasni Shamsuddin. (2018). Measuring social-psychological functioning among Malaysian pre-service teachers. Asia Pacific Journal of Educators and Educations, 33, 109-122. https://doi.org/10.21315/ apjee2018.33.8

To link to this article: https://doi.org/10.21315/apjee2018.33.8

\begin{abstract}
The purpose of this study was to assess social-psychological functioning among pre-service teachers. A total of 693 pre-service teachers (male $=187$, female $=506$ ) from three public universities participated in this cross-sectional survey study. Responses from the 8-item Flourishing Scale was used to assess the status of social-psychological functioning. The results were then analysed using the IBM SPSS Statistics version 23. We reported statistically significant association between social-psychological functioning and gender $(p=.000)$, the first year was significantly lower social-psychological functioning score than that of other groups $(p=.033)$, while, the pure arts students demonstrated significantly higher mean score compared to other fields of study $(p=.000)$. The analysis also showed that there was a moderate and positive relationship between socialpsychological functioning and academic achievement $(r=.402, p=.000)$. In addition, we also provide discussions on possible reasons for these results, with focus on the challenges faced during their transitions into university life.
\end{abstract}

Keywords: academic satisfaction, pre-service teachers, social-psychological functioning, transition, well-being 


\section{INTRODUCTION}

According to Kessler et al. (2007), the age of 18 to 25 is a period of susceptible developmental time. Coincidently, for many, this is also a transition period from high school to university. As such, undergraduates at the university may face difficult time during this transition periods. The difficulties from this transition period may trigger psychopathology or mental problems (Bewick, Koutsopoulou, Miles, Slaa, \& Barkham, 2010; Eisenberg, Gollust, Golberstein, \& Hefner, 2007). This is supported by a substantial number of studies that show mental health problems among university undergraduates (Nordin, Talib, \& Yaacob, 2009; Seim \& Spates, 2010; Verger, Guagliardo, Gilbert, Rouillon, \& Kovess-Masfety, 2009; Yusoff, Abdul Rahim, \& Yaacob, 2010). More importantly, it is also documented that the issue is increasing, both in numbers as well as in severity (Hunt \& Eisenberg, 2010).

Pre-service teachers are not spared from the phenomenon. Apart from the transition difficulties, the pre-service teachers are also going through psychological constructions such as epistemological beliefs, self-awareness, and reflection, as explained by the theory of identity development (Erikson, 1964) and theory of selfcategorisation (Turner, Oakes, Haslam, \& McGarty, 1994). According to Mockler (2011), educational philosophy is an essential part of the development of beliefs among pre-service teachers. Research shows that developing this philosophy can become a massive challenge for them. Britzman (2003) quotes that the problem lies in how to negotiate, construct, and consent the true identity of becoming (effective) teachers. Beauchamp and Thomas (2009) argue that teacher training programme is essential in the construction of this identity. Apart from philosophy, personal well-being is also an integral part for the pre-service teachers (Sammons et al., 2007). Various studies have documented well-being issues among pre-service teachers. For example, Mapfumo, Chitsiko and Chireshe (2012) identify workload as one of the highest sources of stress among pre-service teachers during their practicum. Workloads such as lesson plan and teaching materials became stressor since the pre-service teachers did not know what to prioritise. Furthermore, anxiety in subject matter such as mathematics (Çatlioğlua, Birgina, Costua, \& Gürbüz, 2009) and science (Idowu, 2013) is also well-documented pieces of literature on psychological well-being among the pre-service teachers.

Based on this, we argue that social-psychological functioning among pre-service teachers is an important area to study since understanding professional teacher identity required a social psychological process, and pre-service teachers who had a well-formed sense of personal identity were better prepared to assume the role of professional teacher (Friesen \& Besley, 2013). Social-psychological 
functioning can briefly be conceptualised as a construct that measures two crucial mental well-being dimensions, namely, (1) the hedonic, and (2) the eudaimonic perspectives. According to Diener (1984), hedonic perspective is defined as the affective dimension of well-being such as positive attitude, satisfaction, and enjoyment of life. Meanwhile, the eudaimonic perspective is always associated with the psychological functioning dimension (Keyes, 1998). This includes positive relationships with others, personal growth or respect to or from others. In summary, measurement of the social-psychological functioning is related to how well the pre-service teachers show positive well-being. This study is essential for several reasons. Firstly, lack of social-psychological functioning will influence the effectiveness of the pre-service teachers, especially during their teaching practicum later. Secondly, examining pre-service teachers' perspectives of wellbeing provides insights on problems they are facing and in turn, give insights on their development to become a teacher. All these reasons provide a substantial amount of information towards the betterment of the teacher training programmes. Besides, the information gauged may also be used to help the students. This is essential since success in addressing the challenges enable the pre-service teacher to move on with their transition from high school to university environment.

As such, the purpose of this study is to examine social-psychological functioning among pre-service teachers at Malaysian public universities. The study is also aimed to gauge information on the effect of gender towards social-psychological functioning since literature shows that significant effect was present (Van Droogenbroeck, Spruyt, \& Keppens, 2018; McLafferty et al., 2017; Riecher-Rössler, 2010). We also examine the effect of years of study at the university on the socialpsychological functioning. This is based on past reviews that report a significant effect of age on mental health problems among university students (Farrer, Leach, Griffiths, Christensen, \& Jorm, 2008; Hadjimina \& Furnham, 2017). Also, this study examines the relationship between social-psychological functioning and academic satisfaction among pre-service teachers. We hypothesise that there is a positive association between the two variables since mental health has been reported to have influence on academic performance among undergraduates (Auerbach et al., 2016; Mortier et al., 2015; Zivin, Eisenberg, Gollust, \& Golberstein, 2009).

\section{SCHLOSSBERG TRANSITION THEORY}

As rightly observed by researchers such as Bataineh (2013), Ming and Chee (2015) as well as Kshirsagar and Seema (2016), undergraduates are often facing various challenges at universities which leads to multiple possibilities of success or failure. Those who can address the challenges will end up as having 
the intended academic recognition. These challenges can be understood from the perspective of the Schlossberg Transition Theory (Schlossberg, 1984). According to this theory, transition refers to event, or non-event that results in changed relationships, routines, assumptions, and roles. With regards to the present study, we speculate that anticipated transition (1) from school to university, (2) from high school students to adulthood, and (3) development of educational beliefs, are the leading causes of challenges faced by the undergraduates. There are four factors that influence how a person cope with this transition, namely, situation, self, support, and coping strategies (Goodman, Schlossberg, \& Anderson, 2006). With regards to the situation, it is accepted that every transition is different. As such, each transition is perceived differently, and each person evaluates a similar transition in many different ways. A person also observed transition based on his or her self - through personal (gender, age, socioeconomic status, etc.) or psychological characteristics (values, self-development, etc.). As such, two persons may experience the same transition but address it differently depending upon their gender, age as well as values they hold. A person in transition is also influenced by the kind of support he or she needs. Since each person sees transition in many different ways, it is plausible that he or she requires different support. For example, undergraduates with financial challenges such as in the study of Jariah, Husniah, Laily and Britt (2004), may require financial support, whereas those who face with personal challenges (Syed Mansor \& Hairiza, 2011) may require both emotional and family supports. Finally, an individual's response to the transition (known as coping strategies) also influences how a person address the challenges. Undergraduates with problem-focus strategy may take direct action towards the obstacles such as confrontation. However, if they believe that the challenges are beyond their control, then the undergraduates may opt for emotion-focus strategies which include avoidance of the challenges.

In general, the Schlossberg Transition Theory divides transition process into three distinct phases, namely, moving in, moving through, and moving out. In the moving in stage (particularly during their first and second year of study), the pre-service teachers accept routines, relationships as well as other new aspects of life at university. In the moving through phases, the pre-service teachers are still searching and trying to adapt to the unique situation. If the undergraduates feel comfortable with the new environment, the pre-service teachers will experience this moving through phase positively and vice versa. Examples of positive moving through phase are positive well-being, satisfaction, joy, or excellence in academic. The moving out phase happens typically at the end of their study. In this phase, pre-service teachers seem to be able to address most of the challenges and prepare themselves for teaching profession. It should be noted that the moving in phase will 
start again during the transition from university life to life as a teacher. In short, a transition is a continuous process, and the experience from one transition process should help a person to become more effective and efficient in life. However, these transitions require undergraduates to face various challenges that may have different consequences for different people.

\section{METHODOLOGY}

\section{Participants}

A total of 693 pre-service teachers were employed in this study. The participants include 187 males (27.0\%) and 506 females (73.0\%). The composition of the preservice teachers includes 175 first year (25.3\%), 194 second year (28.0\%), 157 third year $(22.7 \%)$ and 167 final year $(24.1 \%)$. This study opted for purposive sampling so that we were able to obtain a good number of students for each academic year in order to make comparisons regarding their social-psychological functioning. Data were collected during lectures to ensure a good return of the questionnaire. Before administering the questionnaire, we provide brief instruction to the participants regarding the objectives and nature of the study. In general, it only takes about 5 to 10 minutes to complete the questionnaire.

\section{Instrument}

In this study, we employed the Flourishing Scale (FS) to gauge information on their social-psychological functioning. The FS was developed by Diener et al. (2009) to measure human functioning aspects that include positive relationships with others and the purpose of life. It also measures additional characteristics related to human functioning such as feelings of competence and optimism. The FS was translated to Malay language and then converted back to English by a language lecturer. We excluded the category of "Neither agree nor disagree" in the translated version since this category was reported as not functioning well (Bradley, Cunningham, Akers, \& Knutson, 2011; Krosnick, Narayan, \& Smith, 1996). As such, the translated version items are rated on a six-point Likert scale with the response category pattern of strongly disagree-disagree-quite disagreesomewhat agree-agree-strongly agree. The participants with high scores were deemed to possess high positive social-psychological functioning and vice versa. Reliability coefficient (Cronbach's alpha) for the FS was 0.87. Meanwhile, we employed a single-item "I am satisfied with my academic performance" to measure the undergraduates' academic satisfaction. Researchers such as Hoeppner, Kelly, 
Urbanoski and Slaymaker (2011), and Yohannes, Dodd, Morris and Webb (2011) had successfully adapted the single-item procedure in their predictive as well as reliability and validity studies.

\section{Research Design and Statistical analysis}

The present study employed a cross-sectional survey design. The data from research instruments were numerically scored and quantified and were analysed by IBM SPSS 23. Descriptive analysis namely, percentages of responses, means, and standard deviations were employed to describe the basic features of the data in a study. Meanwhile, several inferential statistics were used to provide inference from the data. The independent sample t-tests were employed to infer the difference in the mean score of the social-psychological functioning between male and female. Meanwhile, the analysis of variance (ANOVA) was applied to study the effect of years of study towards the social-psychological functioning among the pre-service teachers. Also, the Pearson correlation analysis was carried out to examine the relationship between social-psychological functioning and academic satisfaction.

\section{RESULTS}

Result from the descriptive analysis (Table 1) indicated that the undergraduates provided the highest score on Item WB1 (I lead a purposeful and meaningful life) $(\mathrm{M}=5.14, \mathrm{SD}=0.94)$ followed by Item WB2 (My social relationships are supportive and rewarding) $(\mathrm{M}=5.04, \mathrm{SD}=0.94)$. Item WB7 (I am optimistic about my future $)(\mathrm{M}=4.99, \mathrm{SD}=0.91)$ completed the top three of the most highly possessed aspects of social-psychological functioning by the participants. In contrast, the pre-service teachers scored the lowest in the elements of their daily activities (Item WB3 [I am engaged and interested in my daily activities], $\mathrm{M}=4.27, \mathrm{SD}=1.18$ ). The pre-service teachers were also did not live to their fullest potential with regards to Item WB4 (I actively contribute to the happiness and well-being of others) and Item WB5 (I am competent and capable in the activities that are important to me), based from low mean score of $4.66(\mathrm{SD}=0.92)$ and $4.68(\mathrm{SD}=0.90)$, respectively. Meanwhile, based from the same statistics, we can conclude that the participants scored moderately for Item WB6 (I am a good person and live a good life, $\mathrm{M}=4.87, \mathrm{SD}=0.95$ ) and Item WB8 (People respect $m e, \mathrm{M}=4.69, \mathrm{SD}=0.95$ ). 
Table 1. Descriptive statistics of the FS

\begin{tabular}{|c|c|c|c|c|c|c|c|c|}
\hline \multirow{2}{*}{ Statement } & \multicolumn{6}{|c|}{ Percentage $(\%)$} & \multirow{2}{*}{ Mean } & \multirow{2}{*}{ S.D. } \\
\hline & SD & $\mathrm{D}$ & QD & QA & A & SA & & \\
\hline $\begin{array}{l}\text { WB1: I lead a purposeful and } \\
\text { meaningful life }\end{array}$ & 1.2 & 0.6 & 3.2 & 13.7 & 40.5 & 40.8 & 5.14 & 0.94 \\
\hline 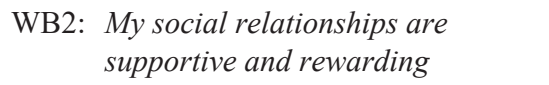 & 0.3 & 2.0 & 4.2 & 14.9 & 44.2 & 34.5 & 5.04 & 0.94 \\
\hline $\begin{array}{l}\text { WB3: I am engaged and interested in } \\
\text { my daily activities }\end{array}$ & 2.0 & 5.2 & 18.5 & 26.7 & 33.6 & 14.0 & 4.27 & 1.18 \\
\hline $\begin{array}{l}\text { WB4: I actively contribute to the } \\
\text { happiness and well-being of others }\end{array}$ & 0.3 & 1.6 & 7.1 & 32.2 & 41.1 & 17.7 & 4.66 & 0.92 \\
\hline $\begin{array}{l}\text { WB5: I am competent and capable in the } \\
\text { activities that are important to me }\end{array}$ & 0.3 & 0.6 & 8.2 & 30.2 & 43.3 & 17.5 & 4.68 & 0.90 \\
\hline $\begin{array}{l}\text { WB6: I am a good person and live a } \\
\text { good life }\end{array}$ & 0.6 & 0.7 & 5.5 & 23.4 & 44.4 & 25.4 & 4.87 & 0.92 \\
\hline WB7: I am optimistic about my future & 0.7 & 0.6 & 3.6 & 20.1 & 44.0 & 31.0 & 4.99 & 0.91 \\
\hline WB8: People respect me & 0.9 & 1.9 & 5.9 & 28.0 & 45.6 & 17.7 & 4.69 & 0.95 \\
\hline
\end{tabular}

Notes: $\mathrm{SD}=$ Strongly Disagree; $\mathrm{D}=$ Disagree; $\mathrm{QD}=$ Quite Disagree; $\mathrm{QA}=$ Quite Agree; $\mathrm{A}=$ Agree, $\mathrm{SA}=$ Strongly Agree; S.D. $=$ Standard Deviation .

An independent sample t-test was carried out to compare the effect of gender toward social-psychological functioning. Result showed that the mean different is statistically significant $[\mathrm{t}(691)=-2.135, p=.033]$. It explains that the mean score of the female undergraduates $(\mathrm{M}=38.65, \mathrm{SD}=4.83)$ is significantly higher than their male counterparts $(\mathrm{M}=37.73, \mathrm{SD}=5.64)$.

A one-way ANOVA was employed to test the effect of years of study on socialpsychological functioning. Results in Table 2 shows that there were significant differences in the mean score of social-psychological functioning between groups $[\mathrm{F}(3,689)=.183, p=.000]$. Post-hoc test using Bonferroni (Table 3) showed that the mean score for the first year was significantly lower than that of other groups. However, there was no significant difference between the second third and final year.

Finally, the present study also investigates the relationship between socialpsychological functioning and academic satisfaction. Result showed both variables were positive and moderately correlated, $r=.402, p=.000$, with socialpsychological functioning contributes to $16.2 \%$ variance in academic satisfaction score. 
Table 2. Results of one-way ANOVA for the effect of years of study on the socialpsychological functioning

\begin{tabular}{lcccc}
\hline Years of study & $\mathrm{N}$ & Mean & $\mathrm{F}$ & $p$-value \\
\hline First & 175 & 37.01 & 7.183 & .000 \\
Second & 194 & 38.56 & & \\
Third & 157 & 38.63 & & \\
Final & 167 & 39.47 & & \\
\hline
\end{tabular}

Table 3. Bonferroni multiple comparisons results

\begin{tabular}{lcc}
\hline Years of study & Mean difference & $p$-value \\
\hline First - Second & -1.54 & .019 \\
First - Third & -1.62 & .020 \\
First - Final & -2.46 & .000 \\
Second - Third & -.074 & 1.00 \\
Second - Final & -.910 & .513 \\
Third - Final & -.910 & .801 \\
\hline
\end{tabular}

\section{DISCUSSION}

Based on the descriptive statistics, it can be seen that the majority of the preservice teachers perceived themselves positively on the main aspects of socialpsychological functioning. For example, the participants endorsed that they lead a purposeful and meaningful life (Item WB1). We believe that the undergraduates understand their priorities and responsibilities as future teachers and focus their effort towards achieving their goals. Besides, one might speculate that leading a purposeful and meaningful life also means having clarity in what they are there to do. This might explain that the pre-service teachers also endorsed high score for WB2, WB6, and WB7 since these items are also associated with having a meaningful life at university. Nevertheless, it should be noted that purposeful and meaningful life not only limited to achieving their academic goals. Undergraduates also sometimes need to step out from their routines and take time to come out from their comfort circle and try something new that also have a purpose and meaning such as engaging in volunteerism or exploring new interests. This will help them in undergoing the transition difficulties highlighted by the Schlossberg Transition Theory. More importantly, the ability to go through the days with meanings and purposes will help the undergraduate to adapt to teaching profession later. 
However, it is quite puzzling when the pre-service teachers rate that they are less engaged and interested in their daily activities (WB3). It is a common conception that when people have a clear purpose in life, they are highly likely to have a better engagement in their daily activities compared with those who don't have. The finding inevitably requires further study especially in trying to understand the reasons why the undergraduates are less interested and engaged in their daily activities. Maybe, as rightly explained by the transition theory, other challenges may influence the finding. For whatever reasons, it is vital for the undergraduates to make their daily activities more interesting. This can be done by engaging with interesting activities as mentioned in the above paragraph. Also, it should be noted that engaging with interesting people also helps to boost our daily life.

The present study reveals that female pre-service teachers demonstrated significantly higher social-psychological functioning scores compared to their male counterparts. Nevertheless, the finding contradicts many other clinical studies on well-being and mental health where women have a higher lifetime prevalence of mood or anxiety disorders (Boyd et al., 2015; Seedat et al., 2009) as well as depression (Kuehner, 2016). Sex hormones, lower self-esteem but a higher tendency for body shame and rumination and lack of gender equality and discrimination are considered as some of the risk factors for the results. Based on the difference between the clinical literature and the non-clinical finding from this study, it is important for future research to close the gap by conducting studies on the social-psychological functioning between the pre-service teachers who show a prevalence of mental health problem (anxiety, depression, etc.) and those who did not. This will provide a clearer understanding of the relationship between mental health and social-psychological functioning both at test level as well as at group level (such as between gender).

Similar to other prevalence of mental health, the result confirms our hypothesis that there is an effect of age towards social-psychological functioning. This is because the longer they stay at the university, the more adaptable they are. In other words, the undergraduates are more able to manage their life independently. They are wiser in dealing with the problems that arise.

This study is also carried out to examine the relationship between socialpsychological functioning and academic satisfaction and the result showed that both variables were moderately correlated. This study helps to add more empirical evidence regarding the inconclusive findings on the relationship between mental health and academic-related variables where contrasting results were reported (Ayyash-Abdo \& Sánchez-Ruiz, 2012; Rüppel, Liersch, \& Walter, 2015; Topham 
$\&$ Moller, 2010;). One possible reason for the result is that there is no pressure for the undergraduates to perform academically and therefore put little treat to their mental well-being state. One might also speculate that the pre-service teachers were satisfied with their teacher training programme.

\section{CONCLUSION}

Based on findings of this study, the data explained that the pre-service teachers showed promising social-psychological functional of mental well-being concerning leading a purposeful and meaningful life that in turn may affect other parts of their university life. Results also revealed that the female pre-service teachers demonstrated significantly higher functioning score compared to the males. Besides, age was also a factor in their hedonic and eudaimonic perspectives. In addition, we documented that there was a positive and moderate correlation between social-functioning and academic satisfaction among pre-service teachers.

\section{ACKNOWLEDGEMENTS}

This research was made possible from the support by Universiti Sains Malaysia Bridging Grant 304.PGURU.6316012.

\section{REFERENCES}

Auerbach, R. P., Alonso, J, Axinn, W. G., Cuijpers, P., Ebert, D. D., Green, J. G., ... Bruffaerts, R. (2016). Mental disorders among college students in the World Health Organization World Mental Health Surveys. Psychological Medicine, 46(14), 2955-2970. https://doi.org/10.1037/abn0000362

Ayyash-Abdo, H., \& Sánchez-Ruiz, M. J. (2012). Subjective wellbeing and its relationship with academic achievement and multilinguality among Lebanese university students. International Journal of Psychology, 47(3), 192-202. https://doi.org/10 $.1080 / 00207594.2011 .614616$

Bataineh, M. (2013). Academic stress among undergraduate student: The case of education faculty at King Saud University. International Interdisciplinary Journal of Education, 2(1), 82-88.

Beauchamp, C., \& Thomas, L. (2009). Understanding teacher identity: An overview of issues in the literature and implications for teacher education. Cambridge Journal of Education, 39(2), 175-189. https://doi.org/10.1080/03057640902902252 
Bewick, B., Koutsopoulou, G., Miles, J., Slaa, E., \& Barkham, M. (2010). Changes in undergraduate students' psychological well-being as they progress through university. Studies in Higher Education, 35(6), 633-645. https://doi. org/10.1080/03075070903216643

Boyd, A., Van de Velde, S., Vilagut, G., de Graaf, R., O’Neill, S., Florescu, S., Alonso, J., Kovess-Masfety, V., \& EU-WMH Investigators. (2015). Gender differences in mental disorders and suicidality in Europe: Results from a large cross-sectional population-based study. Journal of Affective Disorders, 173, 245-254. https://doi. org/10.1016/j.jad.2014.11.002

Bradley, K. D., Cunningham, J. D., Akers, K. S., \& Knutson, N. (2011). Middle category or survey pitfall: Using Rasch modeling to illustrate the middle category measurement flaw. American Educational Research Association. Retrieved from http://www.uky.edu/ kdbrad2/MiddleCategory_AERA2011[1].pdf

Britzman, D. (2003). Practice makes practice: A critical study of learning to teach. Albany, NY: State University of New York Press.

Çatlioğlua, H., Birgina, O., Coştua, S., \& Gürbüz, R. (2009). The level of mathematics anxiety among pre-service elementary school teachers. Procedia - Social and Behavioral Sciences, 1(1), 1578-1581. https://doi.org/10.1016/j.sbspro.2009.01.277

Diener, E. (1984). Subjective well-being. Psychological Bulletin, 95(3), 542-575. https:// doi.org/10.1037/0033-2909.95.3.542

Diener, E., Wirtz, D., Tov, W., Kim-Pierto, C., Choi, D. W., Oishi, S., \& Biswas-Diener, R. (2009). New measures of well-being: Flourishing and positive and negative feelings. Social Indicators Research, 39, 247-266. https://doi.org/10.1007/97890-481-2354-4 12

Eisenberg, D., Gollust, S. E., Golberstein, E., \& Hefner, J. L. (2007). Prevalence and correlates of depression, anxiety, and suicidality among university students. American Journal of Orthopsychiatry, 77(4), 534-542. https://doi. org/10.1037/0002-9432.77.4.534

Erikson, E. H. (1964). Childhood and society (2nd ed). Oxford, England: W. W. Norton \& Co.

Farrer, L., Leach, L., Griffiths, K. M., Christensen, H., \& Jorm, A. F. (2008). Age differences in mental health literacy. BMC Public Health, 8(1), 125. https://doi. org/10.1186/1471-2458-8-125

Friesen, M. D., \& Besley, S. (2013). Teacher identity development in the first year of teacher education: A developmental and social psychological perspective. Teaching and Teacher Education, 36(1), 23-32. https://doi.org/10.1177/0143034316653443

Goodman, J., Schlossberg, N. K., \& Anderson, M. L. (2006). Counselling adults in transition (3rd ed.). New York, NY: Springer.

Hadjimina, E., \& Furnham, A. (2017). Influence of age and gender on mental health literacy of anxiety disorders. Psychiatry Research, 251, 8-13. https://doi.org/10.1016/j. psychres.2017.01.089

Hoeppner, B. B., Kelly, J. F., Urbanoski, K. A., \& Slaymaker, V. (2011). Comparative utility of a single-item vs. multiple-item measure of self-efficacy in predicting relapse among young adults. Journal of Substance Abuse and Treatment, 41(3), 305-312. https://doi.org/10.1016/j.jsat.2011.04.005 
Hunt. J., \& Eisenberg, D. (2010). Mental health problems and help-seeking behavior among college students. Journal of Adolescent Health, 46(1), 3-10. https://doi. org/10.1016/j.jadohealth.2009.08.008

Idowu, O. D. (2013). Nigerian pre-service teachers' science anxiety. Creative Education, 4(5), 304-306. https://doi.org/10.4236/ce.2013.45045

Jariah, M., Husniah, A. R., Laily, P., \& Britt, S. (2004). Financial behavior and problems among university students: Need for financial education. Journal of Personal Finance, 3(1), 82-96.

Kessler, R. C., Amminger, G. P., Aguilar-Gaxiola, S., Alonso, J., Lee, S., \& Ustün, T. B. (2007). Age of onset of mental disorders: a review of recent literature. Current opinion in psychiatry, 20(4), 359-364. https://doi.org/10.1097/YCO. 0b013e32816ebc8c.

Keyes, C. L. M. (1998). Social well-being. Social Psychology Quarterly, 61(2), 121-140. https://doi.org/10.2307/2787065

Krosnick, J. A., Narayan, S., \& Smith, W. R. (1996). Satisficing in surveys: Initial evidence. In M. T. Braverman, \& J. K. Slater (Eds.), Advances in survey research (pp. 29-44). San Francisco: Jossey-Bass.

Kshirsagar, R., \& Seema, A. (2016). A conceptual framework on stress among undergraduates students - A literature review. International Journal of Management, IT and Engineering, 6(8). Retrieved from https://www.researchgate. net/publication/307475322_A_Conceptual_Framework_on_Stress_among_ Undergraduate_students_-_A_Literature_Review

Kuehner C. (2016). Why is depression more common among women than among men? Women's Mental Health, 4(2), 146-158. https://doi.org/10.1016/S22150366(16)30263-2

Mapfumo, J. S., Chitsiko, N., \& Chireshe, R. (2012). Teaching practice generated stressors and coping mechanisms among student teachers in Zimbabwe. South African Journal of Education, 32(2), 155-166. https://doi.org/10.15700/saje.v32n2a601

McLafferty, M., Lapsley, C. R., Ennis, E., Armour, C., Murphy, S., Bunting, B. P., Bjourson, A. J., Murray, E. K., \& O’Neill, S. M. (2017). Mental health, behavioural problems and treatment seeking among students commencing university in Northern Ireland. PLoS ONE, 12(12), e0188785. https://doi.org/10.1371/journal. pone. 0188785

Ming, S. C., \& Chee, S. Low. (2015). Personality, coping and stress among university students. American Journal of Applied Psychology. Special Issue: Psychology of University Students, 4(3-1), 33-38. https://doi.org/10.11648/j. ajap.s.2015040301.16

Mockler, N. (2011). Beyond 'what works': Understanding teacher identity as a practical and political tool. Teachers and Teaching: Theory and Practice, 17(5), 517-528. https://doi.org/10.1080/13540602.2011.602059

Mortier, P., Demyttenaere, K., Auerbach, R. P., Green, J. G., Kessler, R. C., Kiekens, G., Nock, M. K., \& Bruffaerts, R. (2015). The impact of lifetime suicidality on academic performance in college freshmen. Journal of Affective Disorders, 186, 254-260. https://doi.org/10.1016/j.jad.2015.07.030 
Nordin, N. M., Talib, M. A., \& Yaacob, S. N. (2009). Personality, loneliness and mental health among undergraduates at Malaysian universities. European Journal of Scientific Research, 36(2), 285-298.

Riecher-Rössler, A. (2010). Prospects for the classification of mental disorders in women. European Psychiatry, 25(4), 189-96. https://doi.org/10.1016/j.eurpsy.2009.03. 002

Rüppel, F., Liersch, S., \& Walter, U. (2015). The influence of psychological well-being on academic success. Journal of Public Health, 23(1), 15-24. https://doi.org/10.1007/ s10389-015-0654-y

Sammons, P., Day, C., Kington, A., Gu, Q., Stobart, G., \& Smees, R. (2007). Exploring variations in teachers' work, lives and their effects on pupils: Key findings and implications from a longitudinal mix-method study. British Educational Research Journal, 33(5), 681-701. https://doi.org/10.1080/01411920701582264

Schlossberg, N. K. (1984). Counselling adults in transition: Linking theory to practice (1st ed.). New York: Springer Publishing.

Seedat, S., Scott, K. M., Angermeyer, M. C., Berglund, P., Bromet, E. J., Brugha, T. S., ... Kessler, R. C. (2009). Cross-national associations between gender and mental disorders in the World Health Organization World Mental Health Surveys. Archive of General Psychiatry, 66(7), 785-795. https://doi.org/10.1001/ archgenpsychiatry.2009.36

Seim, R. W., \& Spates, C. R. (2010). The prevalence and comorbidity of specific phobias in college students and their interest in receiving treatment. Journal of College Student Psychotherapy, 24(1), 49-58. https://doi.org/10.1080/87568220903400302

Syed Mansor, S. M. S., \& Hairiza, O. (2011). Kategori masalah pelajar tahun satu Kolej Tun Razak, Universiti Teknologi Malaysia, Skudai, Johor. Journal of Educational Psychology and Counselling, 1, 44-58.

Topham, P., \& Moller, N. (2010). New students' psychological well-being and its relation to first year academic performance in a UK university. Counselling and Psychotherapy Research, 11(3), 196-203. https://doi.org/10.1080/14733145.201 0.519043

Turner, J. C., Oakes, P. J. Haslam, A., \& McGarty, C. (1994). Self and collective: Cognition and social context. Personality and Social Psychology Bulletin, 20(5), 454-463. https://doi.org/10.1177/0146167294205002

Van Droogenbroeck, F., Spruyt, B., \& Keppens, G. (2018). Gender differences in mental health problems among adolescents and the role of social support: Results from the Belgian health interview surveys 2008 and 2013. BMC Psychiatry, 18(1), 6. https://doi.org/10.1186/s12888-018-1591-4

Verger, P., Guagliardo, V., Gilbert, F., Rouillon, F., \& Kovess-Masfety, V. (2009). Psychiatric disorders in students in six French universities: 12-month prevalence, comorbidity, impairment and helpseeking. Social Psychiatry Psychiatric Epidemiology, 45(2), 189-199. https://doi.org/10.1007/s00127-009-0055-z

Yohannes, A. M., Dodd, M., Morris, J., \& Webb, K. (2011). Reliability and validity of a single item measure of quality of life scale for adult patients with cystic fibrosis. Health and Quality of Life Outcomes, 9, 105-113. https://doi.org/10.1186/14777525-9-105 
Yusoff, M. S. B., Abdul Rahim, A. F., \& Yaacob, M. J. (2010). Prevalence and sources of stress among Universiti Sains Malaysia medical students. Malaysian Journal of Medical Sciences, 17(1), 30-37.

Zivin, K., Eisenberg, D., Gollust, S. E., \& Golberstein, E. (2009). Persistence of mental health problems and needs in a college student population. Journal of Affective Disorders, 117(3), 180-185. https://doi.org/10.1016/j.jad.2009.01.001 